\title{
INVESTIGATION OF MECHANICAL PROPERTIES ON VINYLESTER BASED BIO-COMPOSITE WITH GELATIN AS RANDOMLY DISTRIBUTED FILLER MATERIAL
}

\author{
Avinash $\mathrm{S}^{1}$, H.G.Hanumantharaju ${ }^{2}$, Vignesh $\mathrm{M}^{3}$, Akash $\mathrm{S}^{4}$ \\ ${ }^{1}$ Student, dept. of Mechanical Engineering, University Visvesvaraya College of Engineering, Bangalore, \\ Karnataka, India \\ ${ }^{2}$ Faculty, dept. of Mechanical Engineering, University Visvesvaraya College of Engineering, Bangalore, \\ Karnataka, India \\ ${ }^{3}$ Student, dept. of Mechanical Engineering, University Visvesvaraya College of Engineering, Bangalore, \\ Karnataka, India \\ ${ }^{4}$ Student, dept. of Mechanical Engineering, Sir MVIT, Bangalore, Karnataka, India
}

\begin{abstract}
In the present work an attempt has been made to develop Bio-composite Material using raw dupion silk fiber reinforced vinylester matrix in addition with gelatin as filler material with varying percentage using hand lay-up method. The experiments namely tensile, flexural and hardness test were conducted on the standard samples prepared. An appreciable improvement was found in the mechanical properties of the Bio-composite, which can be used for variety of applications in the human bone replacement.

The biocomposites were prepared in varying percentage of filler addition (0\%, 10\%, 20\%, and 30\%) and different mechanical tests (tensile, flexure and hardness) were conducted on the samples prepared as per ASTM standards. According to literature survey the human femur bone with tensile strength for female is 30.08 $\pm 7.96 M P$. In this work it was found that tensile strength of $30 \%$ gelatin filled with Dupion silk fiber reinforced vinylester bio-composite material is $26.86 \mathrm{MPa}$.
\end{abstract}

Keywords: Implantation, Bio-composite, Dupion Silk Fiber, Gelatin.

\section{INTRODUCTION}

Engineering Materials are used in medical application to make devices to replace a part or a function of the body in safe, reliably economically, and physiologically acceptable manner. A variety of devices and materials are used in the treatment of disease or injury. Common place examples include suture needles, plates, teeth fillings, etc

Large numbers of polymeric materials alone and in combination with other materials are becoming increasingly significant in the field of biomaterials, as a result composite materials becomes an optimum choice for such applications.

The use of petroleum based products as constituents in polymer matrix composite has raised concerns regarding environmental issue and non-renewability of the resource. Hence the problems associated with it have initiated the efforts to develop Biocomposites. The development of biocomposites has attracted great interests among researchers worldwide. This is because, biocomposite have one or more constituents that are obtained from natural renewable resources also they may have partial or complete degradation and they do not emit any toxic substance during production and disposal process. By successfully producing biocomposite, we may be able to substitute the conventional petroleum-based plastics in various applications.

Bio-Composite are used in biomedical applications for drug/gene delivery and tissue engineering applications. They often mimic the structures of the living materials involved in the process in addition to the strengthening properties of the matrix that was used but still providing biocompatibility, e.g. in creating scaffolds in bone tissue engineering.

Metals and bioceramics for biomedical application have yielded limited successes yet substantial mismatch between their properties and bone tissue persist, thereby punctuating the need for tissue engineered products. However, metals commonly induce stress shielding and will eventually experience wear debris, ultimately leading to implant failure [1]. For example, a fractured bone, fixated with a rigid, non-biodegradable stainless steel implant, has a tendency for re-fracture upon removal of the implant. The bone does not carry sufficient load during the healing process, because the load is carried by the rigid stainless steel [2].

However an implant prepared from biodegradable polymer can be engineered to degrade at a rate that will 
slowly transfer load to the healing bone [3] as shown in Graph-1. Materials used to achieve bone regeneration are diverse but not limited to metals, ceramics, synthetic polymers, naturally derived polymers, and other biocompatible substances. Success has been found by combining these materials as a strategy to eliminate the disadvantages of an individual material.

In the case of materials where starch is used as an additive to a conventional plastic matrix, the polymer in contact with the soil and/or water is attacked by the microbes. The microbes digest the starch, leaving behind a porous, sponge like structure with a high interfacial area, and low structural strength. When the starch component has been depleted, the polymer matrix begins to be degraded by an enzymatic attack. Each reaction results in the scission of a molecule, slowly reducing the weight of the matrix until the entire material has been digested [4].

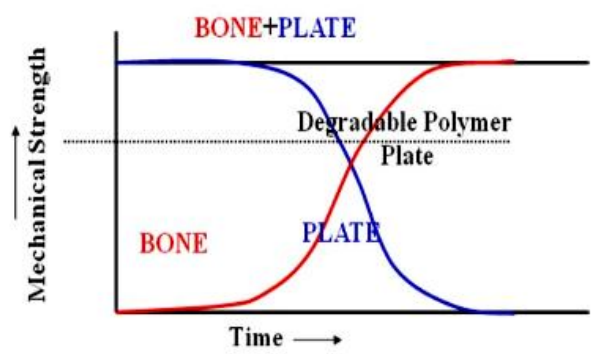

Graph- 1: Mechanical Strength vs Time for Bone and Plate

The current work is an effort to utilize the natural renewable resources to develop biocomposite material for biomedical applications such as bone Plates, bone screws material for both internal, external fixations. The dupion silk fiber is a natural fiber, it is used as reinforcement in vinyl ester resin matrix and gelatin is used as fillers.

\section{PREPARATION OF BIOCOMPOSITES}

\subsection{Materials}

Unsaturated vinylester resin was selected as matrix material, Dupion silk fibers as reinforcement and gelatin as filler material.

Vinyl ester resins having density $1.05 \mathrm{~g} / \mathrm{cm}^{3}$ are becoming increasingly important for fiber reinforced composites. They combine the excellent mechanical, chemical and solvent resistance properties of epoxy resins with the properties found in the unsaturated polyester resins. The chemical structure of vinylester resin is shown in Fig.1

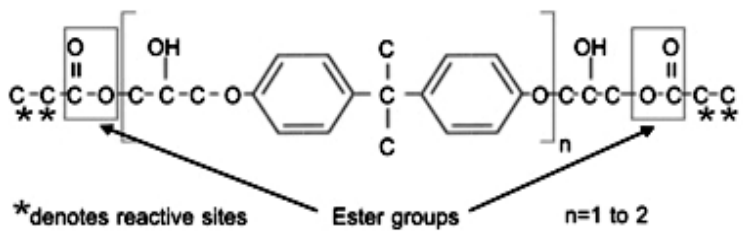

Fig 1: chemical structure of a typical vinylester resin
Silk Dupioni is a type of silk fiber created with the threads from two different silk worms. When two worms spin their cocoons close together, the fibers get tangled up; these naturally tangled fibers are then used together to make the silk thread. In spite of its delicate appearance, silk is relatively robust; the thread is rougher than regular silk as shown in Fig.2.

Gelatin is a protein obtained by boiling skin, tendons, ligaments, and/or bones with water. It is usually obtained from cows or pigs. Gelatin is used in shampoos, face masks, and other cosmetics; as a thickener for fruit gelatins and puddings (such as Jell-O); in candies, marshmallows, cakes, ice cream, and yogurts; on photographic film; and in vitamins as a coating and as capsules, and it is sometimes used to assist in "clearing" wines.

They have good Biocompatibility, Biodegradable and its degradation products are non-toxic.

Table-1: Material Procurement Table

\begin{tabular}{|l|l|l|}
\hline $\begin{array}{l}\text { Sl. } \\
\text { No. }\end{array}$ & MATERIALS & SUPPLIERS \\
\hline 1 & $\begin{array}{l}\text { Unsaturated Vinylester } \\
\text { Resin }\end{array}$ & $\begin{array}{l}\text { Naphtha Resins \& \& } \\
\text { Chemicals } \\
\text { Bangalore, India } \\
\text { Cobalt napthalate } \\
\text { accelerator }\end{array}$ \\
\hline 3 & $\begin{array}{l}\text { Methyl Ethyl Ketone } \\
\text { peroxide catalyst }\end{array}$ & $\begin{array}{l}\text { Silk Exchange Office, } \\
\text { Bangalore, India }\end{array}$ \\
\hline 4 & Dupion Silk Fiber & $\begin{array}{l}\text { Food world, Bangalore, } \\
\text { India }\end{array}$ \\
\hline 5 & Edible Gelatin & \\
\hline
\end{tabular}

\subsection{Technique}

The laminates were prepared by the hand lay-up technique on the rectangular box. The rectangular box of dimension $19 \mathrm{~cm} \times 12 \mathrm{~cm}$ is cleaned with soft brush. A layer of wax is coated on the cleaned surface for the easy removal of the laminate after curing.

Weighed quantity of Gelatin (fillers), Methyl ethyl ketone peroxide (catalyst), Cobalt napthalate (accelerator) are added to Vinyl ester resin taken in the bowl and stirred well for uniform distribution. The weight of constituents to be taken for each specimen is shown in Table- 2 and Table-3. The catalyst and accelerator is taken at $1 \mathrm{ml}$ each for the $100 \mathrm{~g}$ of vinyl ester resin taken.

The first layer of Vinyl ester resin mixture is coated on the wax, later Dupion silk fibers are placed in the mould and the resin mixture is poured and distributed uniformly. Same procedure is repeated until the desired thickness is obtained. Alternate layers of resin and Dupion silk fiber are placed. 


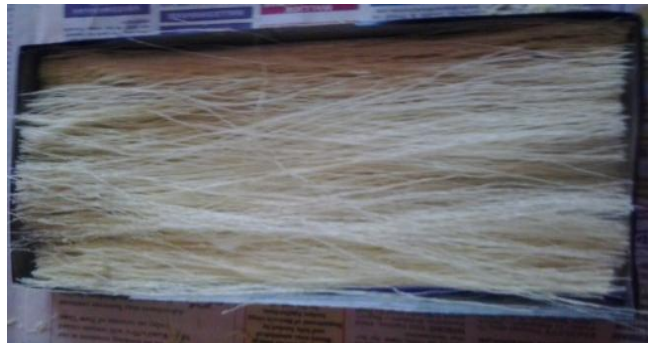

Fig 2: Raw dupion silk fibers

The laminate is cured under light pressure for $2 \mathrm{hrs}$, followed by curing at room temperature for 24 hours. By following the same procedure as said above bio-composite material having filler composition of $0 \%, 10 \%, 20 \%$ and $30 \%$ is prepared. Fig. 3 shows the final laminate.

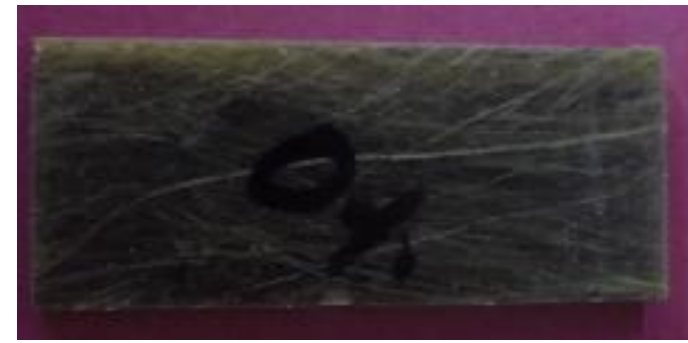

Fig-3: Prepared biocomposite laminate

The prepared Bio-Composite materials are cut into standard ASTM Dimensions using abrasive water jet machine.

\subsection{Sample Preparation Calculation}

- Density of vinyl ester resin $=1.05 \mathrm{~g} / \mathrm{cm}^{3}$

- Density of Gelatin $=0.98 \mathrm{~g} / \mathrm{cm}^{3}$

- $\quad$ Density of silk fiber $=1.33 \mathrm{~g} / \mathrm{cm}^{3}$

- $\quad$ Volume of the mold, $V=190 \times 120 \times 3.5=79800$ $\mathrm{mm}^{3}=79.8 \mathrm{~cm}^{3}=80 \mathrm{~cm}^{3}$

Table-2: Composition of Biocomposite

\begin{tabular}{|l|l|l|l|}
\hline Samples & $\begin{array}{l}\% \text { of } \\
\text { Resin }\end{array}$ & $\begin{array}{l}\% \text { of } \\
\text { Fiber }\end{array}$ & $\begin{array}{l}\% \text { of } \\
\text { Fillers }\end{array}$ \\
\hline A & 90 & 10 & 0 \\
\hline B & 80 & 10 & 10 \\
\hline C & 70 & 10 & 20 \\
\hline D & 60 & 10 & 30 \\
\hline
\end{tabular}

Table -3: Density Calculation of Samples

\begin{tabular}{|l|l|l|l|l|}
\hline $\begin{array}{l}\text { Mass of } \\
\text { Resin } \\
\text { (grams) }\end{array}$ & $\begin{array}{l}\text { Mass of } \\
\text { Fiber } \\
\text { grams) }\end{array}$ & $\begin{array}{l}\text { Mass of } \\
\text { fillers } \\
\text { (grams) }\end{array}$ & $\begin{array}{l}\text { Total } \\
\text { mass } \\
(\text { grams) }\end{array}$ & $\begin{array}{l}\text { Density } \\
\left(\mathrm{g} / \mathrm{cm}^{3}\right)\end{array}$ \\
\hline 75.6 & 10.64 & 0 & 86.24 & 1.078 \\
\hline 67.2 & 10.64 & 7.84 & 85.68 & 1.071 \\
\hline 58.8 & 10.64 & 15.68 & 85.12 & 1.064 \\
\hline 50.4 & 10.64 & 23.52 & 84.56 & 1.057 \\
\hline
\end{tabular}

\section{EXPERIMENTATION}

Mechanical tests such as tensile test, flexural test and hardness tests were conducted on the specimens prepared as per the ASTM standards. The tensile test and flexural test was conducted using $\mathbf{J} \mathrm{J}$ Lloyd universal testing machine and the hardness test was conducted using Rockwell hardness testing machine. All the tests were carried out at room temperature.

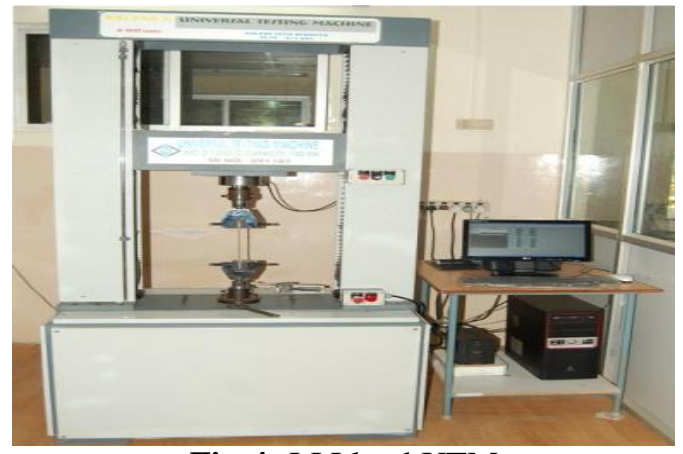

Fig-4: J J Lloyd UTM

\subsection{Tensile Test}

Tensile tests on composite specimens were carried out according to ASTM-D 638 standard to determine tensile strength and to observe the behavior of biocomposites under load.

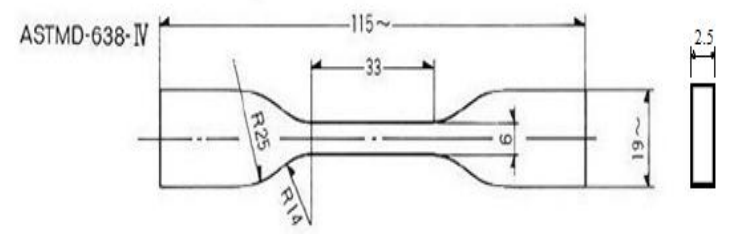

Fig -5: Standard tensile specimen dimensions

\subsection{Flexural Test}

Flexural tests on composite specimens were carried out according to ASTM D-790 standard.
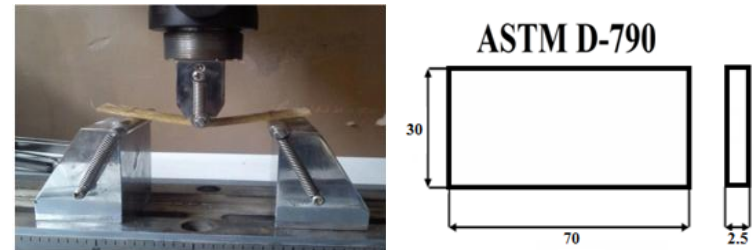

Fig -6: Standard flexural specimen dimensions

\subsection{Rockwell Hardness Test}

The Rockwell hardness is determined by the depth of the indentation in the test material resulting from application of a given force on a specific indenter.

\section{RESULT AND DISCUSSION}

In this section the results obtained from tension, Flexural and Hardness tests are tabulated and represented graphically to analyze the behavior of Biocomposites. 


\subsection{Tensile Test}

The peak load and tensile strength obtained from tensile test conducted on the prepared specimens is tabulated in Table -4 .

Table 4: Tensile Strength readings of each trail

\begin{tabular}{|l|l|l|l|}
\hline \multirow{2}{*}{ SAMPLE } & TRIALS & $\begin{array}{l}\text { PEAK } \\
\text { LOAD } \\
(\mathrm{N})\end{array}$ & $\begin{array}{l}\text { TENSILE } \\
\text { STRENGTH } \\
(\mathrm{N} / \mathrm{mm} 2)\end{array}$ \\
\hline \multirow{2}{*}{$\mathrm{A}$} & 313 & 13.55 & 13.55 \\
\cline { 2 - 4 } & 432 & 17.36 & 17.36 \\
\hline \multirow{2}{*}{$\mathrm{B}$} & 599 & 23.21 & 33.72 \\
\cline { 2 - 4 } & 291 & 11.82 & 37.70 \\
\hline \multirow{2}{*}{$\mathrm{C}$} & 771 & 26.24 & 37.70 \\
\cline { 2 - 4 } & 621 & 20.71 & 28.60 \\
\hline \multirow{2}{*}{$\mathrm{D}$} & 892 & 27.05 & 26.12 \\
\cline { 2 - 4 } & 976 & 26.68 & 18.33 \\
\hline
\end{tabular}

The prepared tensile test specimens before and after the tensile test experiment is shown in the figure-7

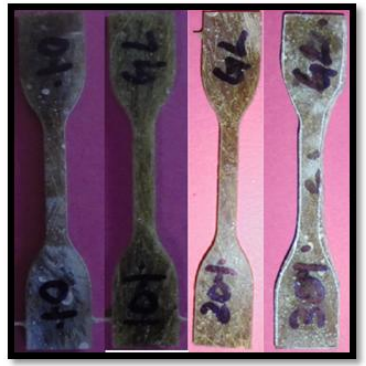

BEFORE TESTING

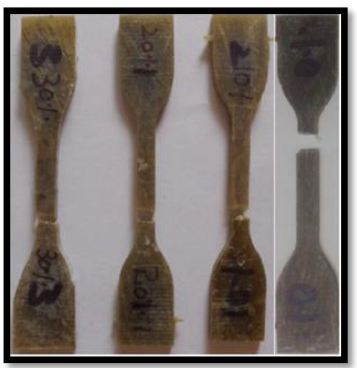

AFTER TESTING

\subsubsection{Effect of Peak Load}

From Graph 2 it can be observed that at all filler content the highest Peak Load is for $30 \%$ filler content biocomposite with a value of $934 \mathrm{~N}$.

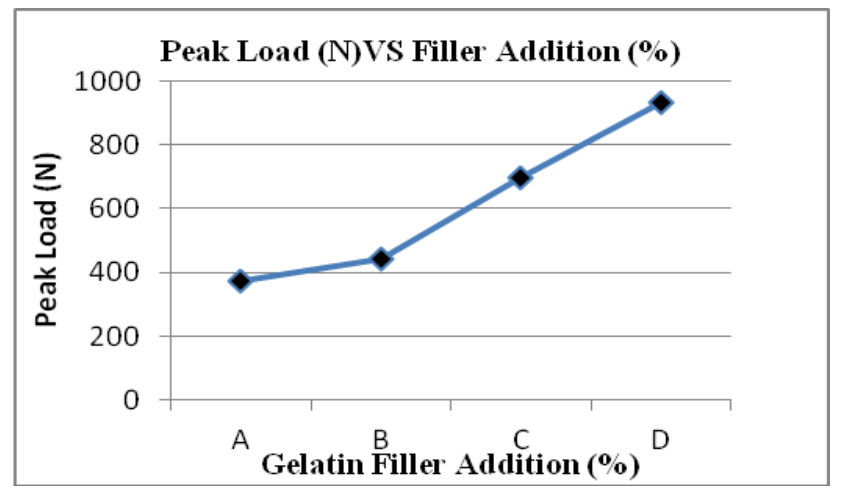

Graph-2: Peak load vs Gelatin filler

\subsubsection{Effect of Ultimate Tensile Strength}

From Graph-3 it can be observed that at all filler content the highest Ultimate Tensile Strength is for $30 \%$ filler content bio-composite with a value of $26.86 \mathrm{Mpa}$.

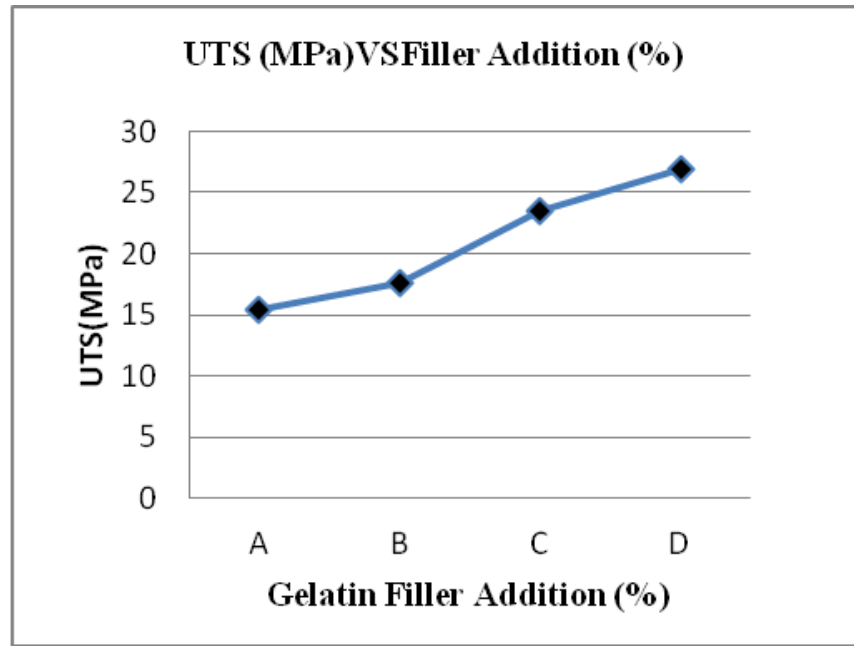

Graph-3: Tensile strength vs Gelatin filler

\subsection{Flexural Test}

The peak load and compression strength obtained from compression test conducted on the prepared specimens is tabulated in table-5.

Table -5: Flexural Strength readings of each trail

\begin{tabular}{|l|l|l|l|}
\hline \multirow{2}{*}{ SAMPLE } & TRIALS & $\begin{array}{l}\text { PEAK } \\
\text { LOAD }(\mathrm{N})\end{array}$ & $\begin{array}{l}\text { FLEXURAL } \\
\text { STRENGTH } \\
\left(\mathrm{N} / \mathrm{mm}^{2}\right)\end{array}$ \\
\hline \multirow{2}{*}{$\mathrm{A}$} & TRIAL 1 & 222 & 37.82 \\
\cline { 2 - 4 } & TRIAL 2 & 217 & 35.13 \\
\hline \multirow{3}{*}{$\mathrm{B}$} & TRIAL 1 & 118 & 23.33 \\
\cline { 2 - 4 } & TRIAL 2 & 102 & 19.77 \\
\hline \multirow{2}{*}{$\mathrm{C}$} & TRIAL 1 & 107 & 17.39 \\
\cline { 2 - 4 } & TRIAL 2 & 69 & 11.26 \\
\hline \multirow{2}{*}{$\mathrm{D}$} & TRIAL 1 & 31 & 6.13 \\
\cline { 2 - 4 } & TRIAL 2 & 71 & 12.67 \\
\hline
\end{tabular}

The prepared flexural test specimens before and after the flexural test experiment is shown in the figure- 8

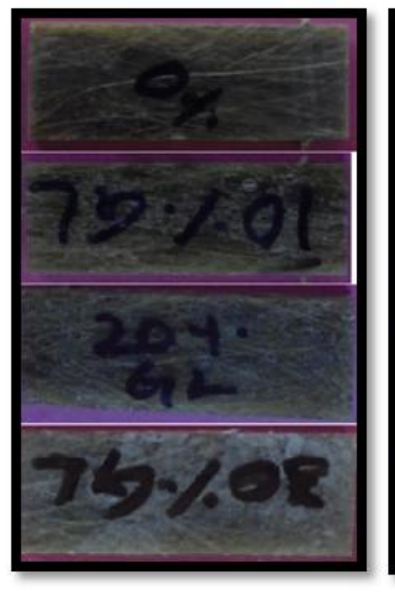

Before Testing

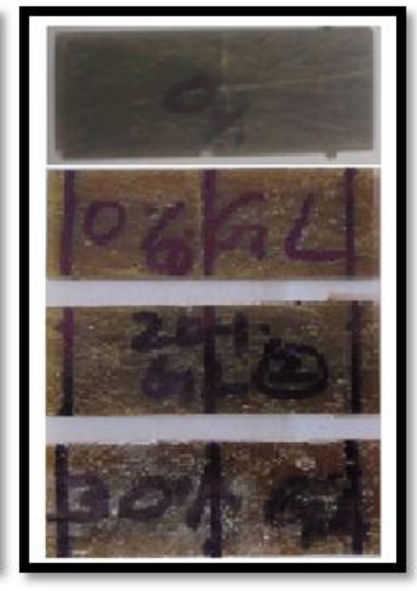

After Testing
Fig-8: Flexural Specimen Before and After Test 


\subsubsection{Effect of Peak Load}

From Graph 4 it can be observed that at all filler content the highest Peak load is for $0 \%$ filler content biocomposite with a value of $219.5 \mathrm{~N}$

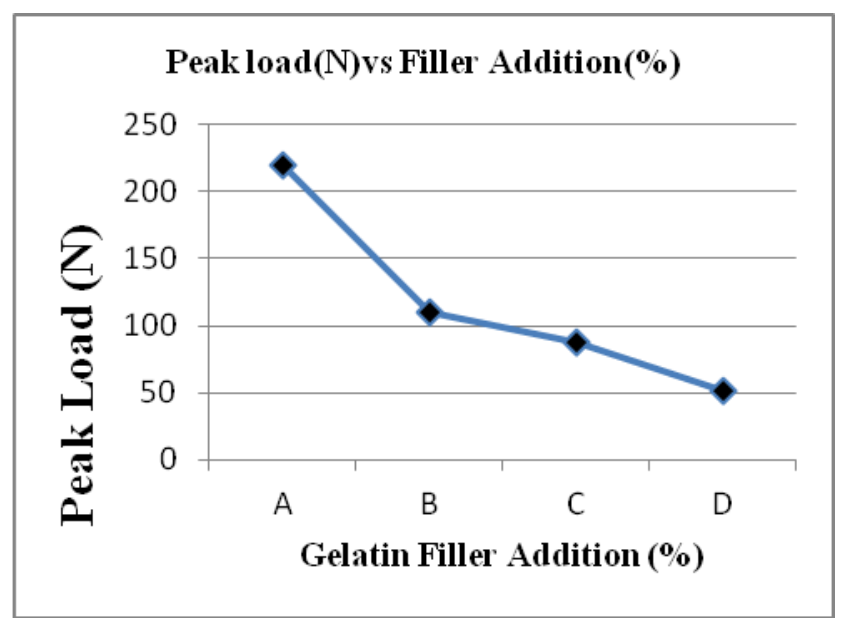

Graph-4: Peak load vs Gelatin filler

\subsubsection{Effect of Flexural Strength}

From Graph-5 it can be observed that at all filler content the highest Flexural Strength is for 0\% filler content biocomposite with a value of $36.47 \mathrm{Mpa}$.

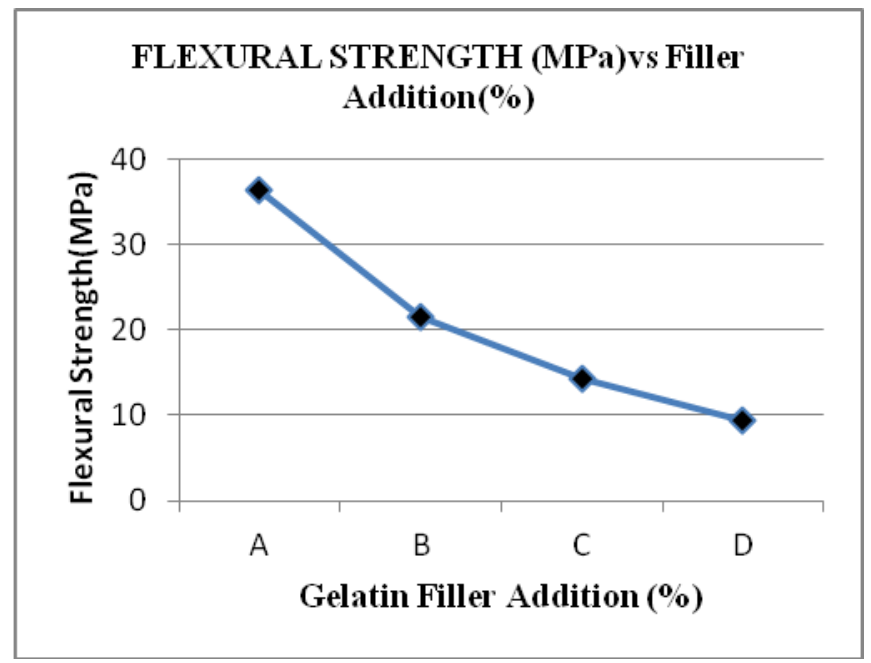

Graph-5: Flexural Strength vs Gelatin Filler

\subsection{Hardness Test}

Hardness is a surface property and is a measure of wear resistance on the surface of the composite. Hardness value increases from $0 \%$ filler content to $30 \%$.The measured hardness number test results are shown in Table 6.

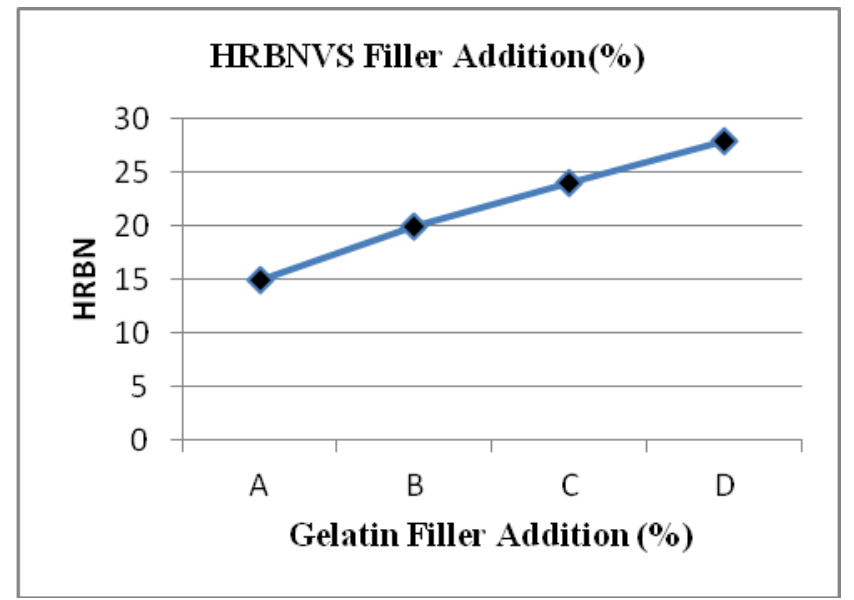

Graph-6: HRBN vs Gelatin filler

Table-6: Measured Hardness Number

\begin{tabular}{|l|l|l|}
\hline SPECIMEN & COMPOSITION HRBN & HR \\
\hline $\mathrm{A}$ & $\begin{array}{l}\text { Vinylester resin }+ \text { Dupion } \\
\text { silk fiber }\end{array}$ & 15 \\
\hline $\mathrm{B}$ & $\begin{array}{l}\text { Vinylester resin + Dupion } \\
\text { silk fiber }+10 \% \text { Gelatin }\end{array}$ & 20 \\
\hline $\mathrm{C}$ & $\begin{array}{l}\text { Vinylester resin }+ \text { Dupion } \\
\text { silk fiber }+20 \% \text { Gelatin }\end{array}$ & 24 \\
\hline $\mathrm{D}$ & $\begin{array}{l}\text { Vinylester resin + Dupion } \\
\text { silk fiber }+30 \% \text { Gelatin }\end{array}$ & 28 \\
\hline
\end{tabular}

\subsection{Morphological Characteristics}

Below figures show the micrograph of sample revealing the morphology of Gelatin Granules and silk fiber reinforcement.

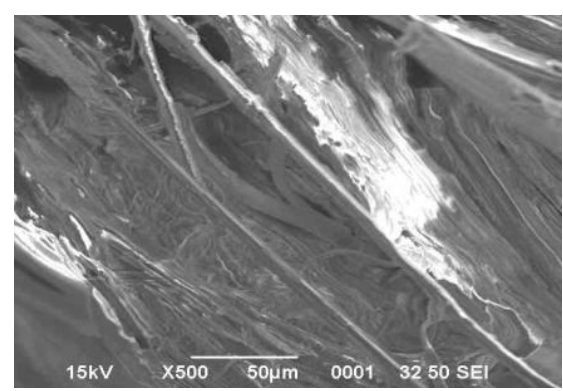

Fig-9: Gelatin Granules \& Silk fibers at 500 magnification

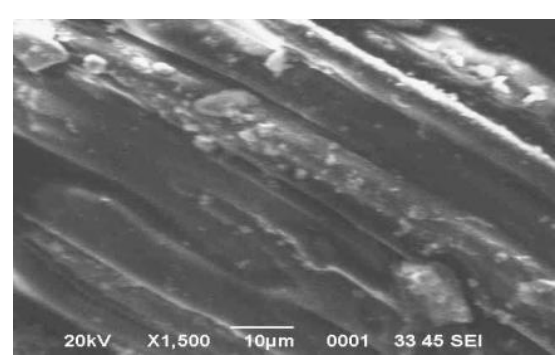

Fig-10: SEM micrograph of untreated Dupion silk fiber The Micrographs reveal that the bonding between reinforcement and matrix is poor and the Gelatin granules are attracted towards the fibers since both are hydrophilic in nature. 


\section{CONCLUSION}

- The present work has been undertaken, with an objective to explore the potential of the natural fiber polymer Bio-composites and to study the mechanical properties of the bio-composites.

- Bio-composites can supplement and eventually replace petroleum based composite materials in several applications thus offering new agricultural, environmental, manufacturing and consumer benefits.

- In mechanical test, it was observed that $30 \%$ filler content has better tensile properties compared to the $0 \%, 10 \%, 20 \%$ filler content, the flexural strength is highest for $0 \%$ filler content, and it reduces for $10 \%, 20 \%, 30 \%$.

- The hardness test results shows that $30 \%$ filler content Biocomposites has better Hardness number.

- In this work Tensile strength of $30 \%$ Gelatin filled Natural (Dupion silk) fiber reinforcement vinylester composite material matches the femur bone tensile strength.

\section{REFERENCES}

[1] H.E. Davis and J.K. Leach, Hybrid and Composite Biomaterials in Tissue Engineering, Topics in Multifunctional Biomaterials and Devices, Ed. N Ashammakhi (C) 2008.

[2] Sangamesh Kumbar, Cato Laurencin, Meng Deng, natural and synthetic biomedical polymers (Elsevier Inc.)

[3] John C. Middleton, Arthur J. Tipton, Synthetic biodegradable polymers as orthopedic devices, Biomaterials 21 (2000) 2335-2346

[4] A. Ashwin Kumar , Karthick. K, and K. P. Arumugam, Biodegradable Polymers and Its Applications, International Journal of Bioscience, Biochemistry and Bioinformatics, Vol. 1, No. 3, September 2011

[5] Dr.Shivappa, Ananda.G.K, Shivakumar.N, "Mechanical Characterization of Rice Husk Flour Reinforced Vinylester Polymer Composite", International Journal of Innovative Research in Science, Engineering and Technology, ISSN: 2319-8753, Vol. 2, Issue 11, November 2013.

[6] M.SAKTHIVEl, S.RAMESH, "Mechanical Properties of Natural Fibre (Banana, Coir, Sisal) Polymer Composites", SCIENCE PARK ISSN: 2321 - 8045, Vol1, Issue-1, July 2013

[7] BIRSAN, I[ulian] G[abriel]; ROMAN, I[gor]; BRIA, V[asile]; UNGUREANU, V[ictor] \& CIRCIUMARU, A[drian], "STARCH - EPOXY COMPOSITES", Annals of DAAAM for 2011 \& Proceedings of the 22nd International DAAAM Symposium, Volume 22, No. 1, ISSN 1726-9679 ISBN 978-3-901509-83-4, 2011.

[8] Shinji Ochi, "Tensile Properties of Bamboo Fiber Reinforced Biodegradable Plastics", International Journal of Composite Materials, 2012, 1-4.

[9] Munikenche Gowda T., Naidu A. C. B., and Rajput Chayya, "Some Mechanical Properties of
Untreated Jute Fabric-Reinforced Polyester Composites", Journal of Composites Part A: Applied Science and Manufacturing, vol.30, pp. 277- 284, 1999.

[10] Manikandan Nair K.C., Diwan S. M., Thomas S., "Tensile properties of short sisal fibre reinforced polystyrene composites" Journal of Applied Polymer Science, New York, vol.60, pp.1483-1497, 1996.

[11] Paramasivam T., Abdulkalam A. P. J., "On the study of natural fibre composites". Fibre Science and Technology, New Delhi, vol.1, pp.85-98, 1974.

[12] Shah A. N. and Lakkad S. C., "Mechanical Properties Of Jute-Reinforced Plastics", Fibre Science and Technology vol.15 pp.41-46, 1981.

[13] Pickering K.L., Li Y., Farrell R.L., \& Lay M., "Interfacial modification of hemp fibre reinforced composites using fungal and alkali treatment". Biobased Material and Bioenergy, vol.1 (1), pp.109-117, 2007.

[14] Gassan J. and Bledzki A.K., "The influence of fiber-surface treatment on the mechanical properties of jute-polypropylene composites". Composites Part-A vol.28, pp.1001-1005, 1997.

[15] K. Murali Mohan Rao, K. Mohana Rao, "Extraction and tensile properties of natural fibers: Vakka, date and bamboo Composite Structures" 77 (2007) 288295.

[16] Dr.KRDinesh1,JagadishSP, Dr. A Thimmanagouda,Dr. Neeta Hatapaki, "Characterization and Investigation of Tensile and Compression Test on Sisal Fiber Reinforcement Epoxy Composite Materials Used as Orthopaedic Implant"

\section{BIOGRAPHIES}

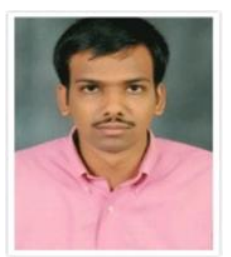

Mr. Avinash S received his B.E degree in Mechanical Engineering from VTU, India (2009), presently doing his M.E degree in advanced materials \& technology at UVCE, Bangalore University, India. Presently his project is based on the field of Biomaterials, replacement of femur bone. His research interests include Composites, Nano-Technology and Cryogenics

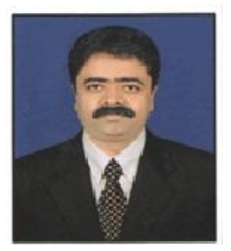

Dr. H.G.Hanumantharaju presently working as assistant professor in UVCE, Bangalore university India. He obtained his B.E degree in mechanical engineering from Mysore University, India (1991) and ME in Machine Design from UVCE, Bangalore University (2004). He obtained his Ph.D in the field of Bio-Materials from Bangalore University (2012). He has guided more than $20 \mathrm{ME}$ students and currently guiding 5 research scholars. His field of interests include bio-materials, composites, stress analysis etc.,

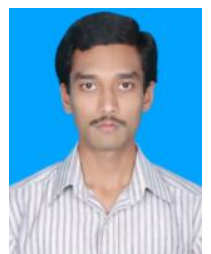

Mr. Vignesh M received his B.E degree in Mechanical Engineering from VTU (2012), presently doing his M.E degree in advanced materials \& technology at UVCE, Bangalore University. Presently 
his project is based on the field of Biomaterials, Functional Bone fixation Devices. His research interests include Composites, Nano-Technology, Cellular Materials and Cryogenics.

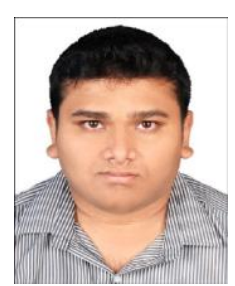

Mr. Akash.S is presently working as ISAGO Trainee member at Menzies aviation Bangalore, India and completed B.E in industrial engineering and management from Sir MVIT, Bangalore (2014). His research interests include Bio-Materials and industrial relation and

management. 